\title{
Fostering learners' (meta)pragmatic awareness through film analysis
}

\author{
Esther Usó-Juan \\ euso@uji.es \\ Universitat Jaume I (Castellón, Spain) \\ Alicia Martínez-Flor \\ aflor@uji.es \\ Universitat Jaume I (Castellón, Spain)
}

Usó-Juan, E., \& Martínez-Flor, A. (2021). Fostering learner's (meta)pragmatic awareness through film analysis. Language Value, 14(1), 85-111. Universitat Jaume I ePress: Castelló, Spain. http://www.languagevalue.uji.es.

July 2021

DOI: 10.6035/languagev.5821

ISSN 1989-7103

\section{ABSTRACT}

Film-based dialogues have been praised in the current work on pragmatics as a potentially useful source that can enhance learners' (meta)pragmatic awareness of the pragmatic phenomena in actual communicative events. Following this view, this paper first outlines the concept of (meta)pragmatic awareness and explains, drawing on McConachy and Spencer-Oatey (2020), the different theoretical perspectives examining the role that awareness plays in developing learners' pragmatic ability. Then, it surveys studies that have reported benefits of bringing audiovisual input through films into the classroom. Finally, the analysis of two film dialogues is presented to illustrate how it may foster learners' awareness of communication as a context-dependent act. Along the way, it also highlights selected research-based techniques that can engage learners in critical film analysis.

Keywords: (Meta)pragmatic Awareness; Sociopragmatics; Pragmalinguistics; Audiovisual Input; Film Analysis. 


\section{INTRODUCTION}

Exposure to contextually appropriate input has been considered necessary for the development of learners' pragmatic competence. In the language classroom context, textbooks are an important source of input which shape learning experiences. However, serious scepticism regarding their appropriacy for presenting learners with accurate language functions has been raised (e.g., Boxer \& Pickering, 1995; Vellenga, 2004; UsóJuan, 2008; Nguyen, 2011; Ren \& Han, 2016; Ton-Nu \& Murray, 2020; among others). This lack of authenticity in the presentation of language functions has given praise to the use of films as a potentially useful source that can present learners with samples of language use in contextualised situations since this enables learners to understand the situational appropriateness or inappropriateness of particular pragmatic actions. Thus, the contextual clues presented in film-based dialogues may bear clear pedagogical value for raising learners' awareness of the pragmatic phenomena in actual communicative events, if learners are presented with activities that engage them in critical analysis (Abrams, 2014, 2016).

In an attempt to shed light on this topic, this paper begins by outlining the concept of (meta)pragmatic awareness and explaining, drawing on McConachy and Spencer-Oatey (2020), the different theoretical perspectives examining the role that awareness plays in developing learners' pragmatic ability, namely those of i) the interlanguage paradigm, ii) sociocultural theory, and iii) intercultural language learning. Following this, it discusses the importance of selecting appropriate materials for raising (meta)pragmatic awareness and reviews studies that have reported benefits of bringing audiovisual input through films into the classroom. This literature review is then followed by the analysis of two film dialogues to exemplify how it may enhance learners' understanding of communication as a context-dependent act. This paper closes by highlighting selected research-based techniques that can provide help in conducting the film analysis. 


\section{LITERATURE REVIEW}

\section{II.1. Defining (meta)pragmatic awareness}

The focus of pragmatics is on the way people convey and interpret meaning in social interaction. Crystal (1997, p. 391) offers a useful definition of pragmatics to examine communicative action at the discourse level: "the study of language from the point of view of users, especially of the choices they make, the constraints they encounter in using language in social interaction and the effects their use of language has on other participants in the act of communication." This definition, which informs this paper, indicates that apart from users and context, interaction also plays a very important role when dealing with pragmatics, since the process of communication does not only focus on the speakers' intentions, but also on the effects those intentions have on the hearers.

Within the context of second/foreign language (L2) learning, pragmatic awareness has played an important role to develop learners' pragmatic competence in instructional contexts. However, its explicit definition and conceptualisation is rarely stated. In fact, problems in differentiating the terms of pragmatic awareness and metapragmatic awareness, have resulted in using these terms interchangeably without a clear explanation of what each of them implies. Recently, however, McConachy and SpencerOatey (2020, p. 394-395) have argued that the term pragmatic awareness is used "to express learners' ability to detect pragmatically (in)appropriate language use, while the term metapragmatic awareness is used when the focus is on learners' ability to verbalise the social meaning of language use." This view is in line with van Compernolle and Kinginger (2013), who consider "pragmatic awareness" to be separate from "metapragmatic awareness" in that the former is about awareness of pragmalinguistics, while the latter is about awareness of sociopragmatics.

This differentiation is therefore clearly related to the classic bifurcation of pragmatics into pragmalinguistics and sociopragmatics. Pragmalinguistics refers to the awareness of the grammatical side of pragmatics and includes, following Bardovi-Harlig (2020, p. 45), "the linguistic resources speakers use for pragmatic purposes" while sociopragmatics deals with the awareness of the relationship between linguistic action and social structure and involves "the rules that guide use of language in society and in context." 
Given the importance of both domains, for the purposes of this paper we will refer to (meta)pragmatic awareness, as a cover term that includes "awareness" of the two aforementioned areas. Indeed, over the past decades the different theoretical perspectives examining the role that awareness plays in developing learners' pragmatic ability have considered these two sides of pragmatics. McConachy and Spencer-Oatey (2020) group these theoretical paradigms into three, namely those of i) the interlanguage paradigm, ii) sociocultural theory and iii) intercultural language learning, which are discussed below.

\section{II.2. Developing (meta)pragmatic awareness}

Within the interlanguage paradigm, the conceptualisation of the pragmatic domain is seen as an understanding of form-function-context mappings of target pragmatic features. In other words, the knowledge of which form(s) to use for conveying intended meaning(s) in context(s), along with the ability to use this knowledge in real-time interaction (Taguchi, 2011). As such, pragmatic awareness development is "closely related to the degree to which learners' awareness of these mappings corresponds to reality" (McConachy \& Spencer-Oatey, 2020, p. 418). Initially, most of the empirical studies on L2 pragmatics were contrastive rather than acquisitional in nature. They examined primary the production of L2 learners' use of target pragmatic features, often in comparison with a native speaker (NS) baseline. Research in this field of study was important in establishing L2 learners' divergence from the L2 pragmatic norms through appropriateness judgments tasks (see Bardovi-Harlig \& Dörnyei, 1998; Schauer, 2006; among others). Since Kasper and Schmidt's (1996) call for studying the development of L2 pragmatic competence, and Kasper's (1997) call for research into the effectiveness of pragmatic instruction, there is now an important number of classroom-based studies that have informed about effective ways of raising learners' (meta)pragmatic awareness in order to develop their L2 pragmatic ability (e.g., Billmyer, 1990; Alcón-Soler, 2007; Takimoto, 2007). These include, among others, tasks such as learners' own discovery of the target pragmatic conventions or learners' engagement in the comparison of their own performance with that of NS behaviour (Takahashi, 2013).

In sociocultural theory, the pragmatic domain is seen as a process of developing analytical and reflective thinking about those sociopragmatic notions that mediate the 
pragmalinguistic choices made by speakers in the accomplishment of social action. In contrast to work in the interlanguage paradigm that focuses on mapping forms onto context, work within sociocultural theory aims to map context onto forms. Accordingly, multiple ways of behaving may be recognised as appropriate, even if they break with social norms to suit learners' identities (van Compernolle, 2014). Pragmatic awareness development is thus related to "achieving conceptual understanding of sociopragmatic concepts as a way of recognising the dynamic social meaning that speakers in interaction aim to construct and how this influences the interlocutors" (McConachy \& SpencerOatey, 2020, p. 418). Empirical studies on L2 pragmatics from a sociocultural perspective have gone beyond pragmatic prescriptions and have helped to illuminate how learners construct pragmatic understanding by meaning negotiation (e.g., Kinginger \& Belz, 2005; van Compernolle \& Kinginger, 2013; van Compernolle, Gomez-Laich \& Weber, 2016). Within these studies, the central role of verbalised reflection tasks (i.e., tasks which require learners to externalise their thinking) has been highlighted to guide learners towards eliciting their (meta)pragmatic awareness (van Compernolle, 2014).

Finally, in intercultural language learning, the pragmatic domain is concerned with the way language systems are used in social encounters between speakers who have different first language (L1) and cultures, yet communicate in a common language (Kecskes, 2013). Thus, the development of (meta)pragmatic awareness within an intercultural orientation is understood as "the learners' recognition of how cultural assumptions shape the way individuals attempt to construct and interpret impressions such as politeness, formality etc." (McConachy \& Spencer-Oatey, 2020, p. 419). The scant research studies in this field have contributed to understand how the powerful component of culture shapes L1 and L2 language use in a variety of contexts (e.g., Liddicoat, 2006; Liddicoat \& Scarino, 2013; Kecskes, 2015). Here, explicit talk about observed intercultural interactions through collaborative dialogue has been shown to be effective in analysing appropriate pragmatic language use (McConachy, 2018).

\section{II.3. Selecting materials for promoting (meta)pragmatic awareness}

Empirical studies on pragmatic development conducted within the interlanguage paradigm or within a sociocultural or intercultural orientation have suggested that awareness-raising is an effective approach for developing learners' L2 pragmatics as well 
as assisting them in utilising the pragmatic resources they already possess. Despite these beneficial effects, L2 instruction focuses largely on grammar and ignores pragmatic improvement. A possible reason for this reluctance to teaching pragmatics could be attributed to the difficulty it implies, as pragmatic behaviour varies to a large extent depending on social and cultural contexts. Sykes $(2013$, p. 73$)$ identifies eight challenges to pragmatic instruction: i) limited theoretical support for curricular development, ii) lack of authentic input in teaching materials, iii) lack of instructor knowledge, iv) a dominant focus on micro features of language in the foreign language context, v) time limitations in the classroom, vi) individual student differences and learning subjectivity, vii) feedback and assessment challenges, and viii) immense dialectal variation. Although all categories are worthy of consideration, the most relevant for this article is the second, lack of authentic input in teaching materials, which has been referred to as "the front line of pedagogical revolution" (Bardovi-Harlig, 2020, p. 54).

Together with output and feedback, input has been considered one of the three necessary conditions for learners' development of their pragmatic competence (Martínez-Flor \& Usó-Juan, 2010, 2020). Input refers to the language samples learners are exposed to. For pragmatics learning to take place, learners need not only to be exposed to appropriate input but also to understand it. In this regard, the setting in which the language is being learned or taught affects considerably the extent to which such an input can be understood and assimilated. In a second language context, learners may be exposed to the target language outside the classroom as well as experience opportunities for cross-cultural communication (Martínez-Flor, 2007; Usó-Juan, 2007). This provides learners with excellent opportunities to acquire the language and develop pragmatic competence. In contrast, in a foreign language setting, learners' opportunities to be in contact with authentic situations in the target language (TL) are limited and, therefore, the chance to develop their pragmatic competence depends considerably on the pragmatic input presented to them in the classroom. According to LoCastro (2003), learners are exposed to three types of input in this particular context, namely those of the teacher, the materials, and other learners. It is the second of these types, namely the materials learners are exposed to, the relevant one for the purposes of this paper. 
The use of appropriate teaching materials to develop pragmatic competence has been regarded a key source of input to learners in the classroom. Research on the pragmatic input presented in textbooks has focused on a variety of speech acts and their realisation strategies (e.g., Boxer \& Pickering, 1995; Vellenga, 2004; Usó-Juan, 2008; Nguyen, 2011; Ren \& Han, 2016, Ton-Nu \& Murray, 2020; among others). It is evident from such an examination that textbooks are deficient in representing L2 pragmatics since the speech act realisations presented rarely match those used in authentic exchanges. A possible explanation for such a lack of presentation of authentic language models in textbooks may be that such material relies heavily on the intuitions of native textbook developers about speech act realisations rather than on empirical research (Boxer, 2003; Cohen \& Ishihara, 2013).

In line with all the previous constraints, Boxer (2003) also claims that it would only be when spontaneous speech is captured in authentic data for language materials that we might begin to teach the underlying strategies of speech behaviour. Therefore, there is a need to base materials and teaching practices on natural language data if our aim is to provide the necessary conditions in the classroom to make learners aware of communicatively appropriate patterns (see Tatsuki, 2019 for recommendations on instructional material development in L2 pragmatics). Several researchers have already proposed different alternatives to challenge this artificial presentation of conversations in textbooks, such as the use of spoken corpora (Schauer \& Adolphs, 2006; Jiang, 2006; Bardovi-Harlig, Mossman \& Vellenga, 2015; Barron, 2019), the use of new technologies such as synchronous and asynchronous computer-mediated communication (Belz \& Kinginger, 2002, 2003; González-Lloret, 2018, 2019) or the use of audiovisual sources, such as video, films and TV (Rose, 2001; Martínez-Flor \& Fernández-Guerra, 2002; Grant \& Starks, 2001; Kite \& Tatsuki, 2005; Tatsuki \& Nishizawa 2005; Martínez-Flor, 2007; Fernández-Guerra, 2008).

Focusing on audiovisual sources, the above-mentioned studies have reported the benefits of using video input to enhance the language learning process in the classroom since audiovisual aids may expose learners with contextualised language samples as well as strengthen their audio/visual linguistic perceptions (Arthur, 1999; Canning-Wilson, 2000; Sherman, 2003). Additionally, this material has also been praised for motivating 
learners and activating their cognitive domains (Ryan, 1998), helping them visualise words and meanings (Canning-Wilson, 2000), showing them a variety of accents, dialects and situations (Yamanaka, 2003), making them observe different social realities, cultural conventions and non-verbal aspects of communication (Segovia, 2008) as well as changing the classroom routines (Swaffar \& Vlatten, 1997). All these features are, therefore, of crucial importance when developing pragmatics in the L2 classroom, since students should be aware of the relationship between participants when performing particular pragmatic features and also of the contextual factors affecting their conversational interaction. Thus, through the exposure to audiovisual sources, and particularly films, learners' (meta)pragmatic awareness of all these key aspects for successful L2 pragmatics development, can be raised.

\section{II.4. Using films to raise (meta)pragmatic awareness}

The potential of films as a way of presenting rich and contextually appropriate pragmatic input in a variety of cultural contexts has been highlighted by many researchers such as Rose (1993, 1994, 1997, 1999, 2001), Martínez-Flor and Fernández-Guerra (2002), Kite and Tatsuki (2005), Martínez-Flor (2007) and Abrams (2014, 2016), among others.

In fact, in his seminal paper, Rose (1997, p. 283) praised the use of scenes from films as opportunities to observe pragmatic language use in context. He, therefore, conducted a good number of studies involving activities designed to implement the use of film in the classroom (Rose 1993, 1994, 1999) and to determine the authenticity of film excerpts when compared to naturally occurring data (Rose 1997, 2001). In his 1997 study, Rose compared the occurrence of compliments in forty-six American films with a corpus of compliments (collected by Manes \& Wolfson, 1981) and found that, for global categories, such as the distribution of syntactic formulae, the film data closely matched naturally occurring speech. Later, Rose (2001) supported this finding in a follow-up study which showed that syntactic formulae, compliment topic and compliment strategy responses were found to be similar in film data and in naturally occurring speech (i.e., pragmalinguistic forms), although some differences were identified regarding gender distribution (i.e., sociopragmatic features). 
Focusing on a different speech act (i.e., apologies), Kite and Tatsuki (2005) obtained similar results to those reported by Rose (2001), since the pragmalinguistic strategies employed to express apologies in both films and naturally occurring discourse were equivalent, whereas sociopragmatic factors, such as the gender of participants, also appeared to differ in both sources. Martínez-Flor and Fernández-Guerra (2002) compared the occurrence of three exhortative speech acts, namely requests, suggestions and advice acts, in coursebooks and films. The authors found that in contrast to the artificial and inappropriate presentation of these speech acts in the textbooks analysed, the occurrence of them in the films that were examined appeared highly contextualised and displayed a wide variety of linguistic formulae. The focus of Martínez-Flor's (2007) study was that of examining the presentation of request modification devices in different films. Results indicated that all types of internal and external modification devices were found in the data, thus showing the whole variety of pragmalinguistic forms that may be used to modify the speech act of requesting. Additionally, all devices appeared in fully contextualised situations illustrating therefore the potential of films in helping learners raise their pragmatic awareness towards those sociopragmatic factors that influence an appropriate use of these modifiers.

More recently, Abrams $(2014,2016)$ analysed the potential of film for developing German beginning L2 learners' awareness of different pragmatic aspects. In her 2014 study, the author implemented an instructional study to examine whether film exposure was beneficial to make learners understand politeness issues, and other pragmatic aspects such as the purpose of conversations or expressions of agreement and disagreement. Results showed that films can serve as a springboard for social interaction through contextualised discourse-length language samples and also revealed that films can provide scaffolding for teaching pragmatics. In a later classroom study, Abrams (2016) examined how authentic filmic materials, in contrast with textbook models, may help learners develop their pragmatic skills in collaborative dialogues. Acknowledging the fact that sociopragmatic knowledge and pragmatic awareness precede pragmalinguistic knowledge, findings from her research reported that film-based dialogues prompted more pragmatically nuanced interactions than did textbook dialogues. Indeed, learners incorporated communicative patterns used in films into their own dialogues. 
All this research has therefore reported the benefits of bringing audiovisual input through films into the classroom, since learners are exposed to authentic language samples in which different pragmatic features appear contextualised. However, this particular source has also received criticism since its validity has been questioned (Rose, 2001). Indeed, several researchers have argued that film-based dialogues fail to reflect the pragmatics of ordinary speech (Kozloff, 2000; Cohen, 2008; Rossi, 2011; Toolan, 2011). Particularly, in the recent study conducted by Ryan and Granville (2020), which aimed at examining invitation sequences and the openings and closings of phone calls in films and in daily life, the authors reported a clear mismatch between the pragmatics of film dialogues and ordinary conversations. After a rigorous conversational analysis of turn-by-turn progression sequences, findings revealed that some aspects of the "sequencing of talk" are not represented in film dialogues, suggesting that films may reflect inaccurate models of conversations (Ryan \& Granville, 2020, p. 11).

Despite the drawbacks that may be attributed to films regarding their planned and scripted nature, the potential they offer as a rich and valuable source of classroom input in foreign language contexts is undisputed. In fact, as Abrams (2016, p. 38) highlights, films may represent for beginning $L 2$ learners an easier "entry-point" for learning L2 pragmatics than real input, "whose pace and shifts in topics could prove too challenging."

\section{ANALYSING FILM-BASED DIALOGUES FOR ACTIVATING LEARNERS' (META)PRAGMATIC AWARENESS OF REQUEST DEVICES}

Both theory and research highlight the important role of (meta)pragmatic awareness in learning L2 pragmatics. Thus, focusing on a particular pragmatic feature, that of request modification devices, it is the aim of this section to illustrate how learners' (meta)pragmatic knowledge can be raised in the classroom through the analysis of filmbased dialogues. Before presenting the analysis, a brief explanation of this pragmatic aspect is given. 


\section{III.1. Request modification devices}

Request modification devices refer to one of the main parts into which the speech act of requesting is divided into, that is, the head act and these same devices (Trosborg, 1995; Usó-Juan, 2010). Whereas the head act consists of the main utterance which has the function of requesting and can stand by itself, modification devices are optional elements that may follow and/or precede the request head act. These elements can be further classified into two groups, namely internal (i.e., items that appear within the same request head act) and external (i.e., devices that occur in the immediate linguistic context surrounding the request head act). Drawing on previous research (House \& Kasper, 1981; Trosborg, 1995; Nikula, 1996; Sifianou, 1999; Achiba, 2003), a workable classification of those devices is presented for pedagogic purposes with examples extracted from film excerpts (Martínez-Flor, 2007). Three subtypes of internal mitigating devices (see 1-3 below), five of external modification devices (see 4-8 below) and the marker "please", which can be used either in an internal or external position (see 9 below), have been identified:

1. openers - i.e., opening items and expressions that introduce the intended request (e.g., Gentlemen, would you mind leaving us, please?)

2. softeners - i.e., items that soften the impositive force of the request (e.g., Listen, can I talk to you for a second?)

3. fillers - i.e., items, such as hesitators (e.g., er, erm), cajolers (e.g., you know, you see, I mean), appealers (e.g., OK? right?) or attention-getters (e.g., excuse me, hello, Mr. Smith), that fill in gaps in the interaction (e.g., Excuse me, can you tell me how to get to Beverly Hills?; Oscar, lower it a bit, would you?)

4. preparators - i.e., devices that prepare the addressee for the subsequent request (e.g., Colonel, I do have to ask you a couple of questions about September the $6^{\text {th }}$ )

5. grounders - i.e., devices that give reasons that justify the request (i.e., Call my family, I'd like them to have dinner with me tonight).

6. disarmers - i.e., devices that are employed to avoid the possibility of a refusal (e.g., Colonel Jessep, if it's not too much trouble, l'd like a copy of the transfer order, Sir) 
7. expanders - i.e., devices related to repetition that are used to indicate tentativeness (e.g., Can you take him to the airport in the morning? [...] can you pick him up at 8.30?)

8. promise of a reward - i.e., devices that are used by the requester so that his/her request may be accomplished (e.g., [...] she wants a bottle of wine [...] / would promise to send you the money)

9. marker "please" - (e.g., Would you hang up please and I'll call your machine?)

All the above modifiers play an important role in either mitigating or intensifying the requestive pragmatic force. In fact, speakers' use of these items (or their failure to do so) may be crucial for the actual fulfilment of their request moves. Therefore, teachers need to develop learners' (meta)pragmatic awareness regarding these particular pragmatic features, which can be achieved by engaging them in critical analysis of film dialogues, as reported next.

\section{III.2. Contextual and linguistic analysis for raising learners' (meta)pragmatic awareness of request modifiers}

Some considerations should be addressed before presenting the following sample analysis for fostering learners' (meta)pragmatic awareness of request modifiers through film dialogues. First, and echoing the view of Abrams (2016, p. 25), teachers should help learners understand that form-function mappings are shaped by contextual factors and that "language use varies both across speakers and even in the speech of an individual speaker." Moreover, they should also help learners understand that interactions are not dependent on NS norms but are the result of negotiations of meanings between the speakers in a particular communicative event. Therefore, presenting learners with an ample variety of sociocultural situations that show contrasting dialogues would assist them make informed decisions about which particular choices they make for their own interactions. To facilitate this endeavour, conducting a pragmatic analysis of film dialogues may facilitate learners' understanding of communication as a collaborative and context-dependent act. Such an analysis should focus first on the contextual factors that characterise a particular conversation, and then on the variety of linguistic elements 
that may be consciously chosen to communicate in that particular sociocultural situation.

Starting with the contextual analysis, the well-known model of SPEAKING developed by Hymes in 1974 (which has been recently employed by McConachy, 2009; Zand-Vakili, Kashani \& Tabandeh, 2012; Abrams, 2016; Zhao \& Liu, 2019; among others) may be used as the guiding framework to examine all the different elements of a film dialogue. The word SPEAKING introduces the eight components which underline the construction and interpretation of any conversation, namely Setting (S) (i.e., physical circumstances), Participants (P) (i.e., speakers and audience), Ends (E) (i.e., purposes), Act sequence ( $A$ ) (i.e., form and order of events), Key (K) (i.e., tone of conversation), Instrumentalities (I) (i.e., style of speech), Norm (N) (i.e., rules of interaction) and Genre (G) (i.e., kind of speech event). As noted by McConachy (2009, p. 120-122), this model allows teachers to develop analytical questions for guiding learners in a contextual analysis of conversations and increasing thus their understanding of pragmatics as a contextdependent phenomenon. This author distinguishes four question types that can be formulated in relation to the eight components of the SPEAKING framework: i) language-based questions (i.e., Why does person $X$ say 'I see'?), ii) function-based questions (i.e. Where does speaker $X$ show 'interest'?), iii) comparative questions (i.e., In your culture do people apologise like this?) and iv) general speculative questions (i.e. Why do you think the man refused the invitation?). By means of these questions, knowledge of the sociocultural factors that are involved in a film dialogue can be activated raising thus learners' (meta)pragmatic awareness about how they condition the selection of the specific linguistic form used to express a given pragmatic act.

Moving to the linguistic analysis, the different awareness-raising questions developed by Usó-Juan and Martínez-Flor (2008) may be used as a guide to direct learners' attention to the forms that interactants have chosen to express their communicative intentions. Those questions refer to the grammatical side of pragmatics and address the resources for conveying particular communicative acts. Such resources include pragmatic strategies like directness and indirectness, pragmatic routines, and a range of modification devices that can intensify or soften the communicative act. Focusing specifically on request mitigating devices, the authors present reflective questions 
related to i) the forms of the two parts of the requestive communicative act (i.e., the request head act and the request modification devices), ii) the different types of request modifiers (i.e., internal and external), and iii) the different functions that they may have (see subsection 6.1 above) (the original questions are presented in the Appendix). Using these questions, knowledge of the pragmalinguistic forms that appear in a given film dialogue can be activated raising thus learners' (meta)pragmatic awareness about why a particular linguistic form has been chosen depending on the contextual factors that characterise such interaction.

Drawing on McConachy's (2009) analytical questions based on Hymes' (1974) model for a contextual analysis, and Usó-Juan and Martínez-Flor's (2008) awareness-raising questions for a linguistic analysis, we provide a pragmatic analysis of two dialogues taken from the films The Day after Tomorrow (2004) and My Big Fat Greek Wedding (2002), respectively. These two films were chosen because they involve situations in different contextual and social settings, portray different participant relationships as well as highlight cultural stereotypes. First, a scene analysis is conducted to identify relevant sociocultural factors in the dialogues. Then, general analytical questions for each of the eight components of the SPEAKING framework are generated for a contextual analysis, together with general reflective questions for a linguistic analysis.

The first dialogue comes from the film The Day after Tomorrow and concerns a casual meeting that took place in the street between two scientists, Jack who gave a presentation in a conference about his field of research, and Terry who listened to Jack's presentation. Although both are professors and have the same social status, Jack is in a higher position of authority because he is the invited speaker in the conference. In dialogue 1 , they meet in person and Terry makes a mitigated request for talking about Jack's theory on abrupt climate shift.

Dialogue 1. (00:08:06)

1. Terry: I enjoyed your testimony, professor. It was very spirited.

2. Jack: Oh, thank you. That's what we're here for, right? Put on a good show?

3. Terry: Quite. I was wondering if I could talk to you about your theory on abrupt climate

4. $\quad$ shift. The name's Rapson. Terry Rapson.

5. Jack Professor Rapson? Of the Hedland Center?

6. Terry: That's me.

7. Jack I've read your work on ocean currents.

8. Terry: What do you say to a spot of tea?

9. Jack Absolutely, if we can hail a cab. 
10. Terry: [whistles] Over here!

This dialogue starts with Terry flattering Jack for his presentation (line 1) and with Jack thanking him for the compliment (line 2). After this, Terry makes a mitigated request to Jack for talking about his theory of abrupt climate (line 3) and introduces himself (line 4). Jack also acknowledges he is familiarised with Terry's research work (line 7). After this, Terry invites Jack to have tea in a quite informal way, using the informal expression "a spot of" (line 8), and Jack accepts the invitation in a delightful way (line 9). Finally, Jack whistles loud to hail a taxi (line 10). Table 1 provides an explanation of this dialogue by following the eight components of the SPEAKING framework.

Table 1. Analysis of Dialogue 1.

\begin{tabular}{|c|l|}
\hline Components & \multicolumn{1}{c|}{ Explanation } \\
\hline S & $\begin{array}{l}\text { After the meeting in new Delhi (India), where it is snowing, Jack is waiting for a taxi, } \\
\text { and Terry Rapson goes to talk to him. }\end{array}$ \\
\hline P & Speakers are Jack and Terry. \\
\hline E & Terry wants to discuss with Jack about his theory on abrupt climate shift. \\
\hline A & $\begin{array}{l}\text { Terry praises Jack's presentation, and then he makes him a request for talking about } \\
\text { his theory on abrupt climate shift. Finally, he invites Jack to have tea, and he accepts } \\
\text { the invitation. }\end{array}$ \\
\hline K & Terry is determined to have a conversation with Jack. \\
\hline I & $\begin{array}{l}\text { Formal conversation between two scientists who did not know each other in person, } \\
\text { but they were familiarised with each other's research work. However, after the } \\
\text { presentation, the tone becomes more informal. }\end{array}$ \\
\hline N & $\begin{array}{l}\text { Between scientists, it is common to share their views about the research they are } \\
\text { conducting. }\end{array}$ \\
\hline G & Face-to-face conversation. \\
\hline
\end{tabular}

The second dialogue comes from the film My Big Fat Greek Wedding and involves a conversation between Toula, a Greek female adult, and her father. She wants to talk to him because she would like to go to college. This situation reflects a familiar participant relationship, since it is between a father and his daughter (i.e., close social distance). However, given the customs in their family, the request Toula has to make to her father, a person of superior power, is very face-threatening and involves a high degree of imposition in that particular family. In dialogue 2 , Toula hesitates a lot when making the request because she is afraid of her father's reaction. 
Dialogue 2. (00:15:40)

1. Toula: Dad? I've been going through our inventory, and I've noticed that we've been

2. doing a lot of unnecessary ordering [...] So, I was thinking that maybe we

3. should update our system [...] like, we could get a computer [...] I don't

4. know if you remember, but I got all A's in computers but there's a lot of new

5. staff to learn now, so [...] eh [...] if you want, I could go to college and take

$6 . \quad$ a few courses.

7. Father: Why? Why you want to leave me?

8. Toula: I'm not leaving you. Don't you want me to do something with my life?

9. Father: Yes. Get married, make babies. You look so old!

This dialogue starts with Toula addressing to her father as "dad" in a familiar, informal way (line 1). After a long hesitation (line 2), Toula suggests him updating the system and buying a computer (line 3). Then, she makes an elaborated explanation about her marks in subjects dealing with computers (line 4) before making a request to her father for going to college and take some courses (lines 5-6). After listening to her, her father feels shocked since his higher status is being threatened, and he asks her why she wants to abandon him (line 7). Toula's response is blunt, and she tells him she is not leaving him, trying to reconfirm her request of going to college, something that because of her condition of being a woman is not considered to be correct in her family (line 8). Finally, her father reaffirms his position by telling her what she, as a woman in the Greek culture, must do: get married and become a mother and housewife (line 9). Additionally, his tone is derogatory and highly offensive when he refers to her as being aged (line 9). Table 2 provides an explanation of this scene by considering the eight components of the SPEAKING framework.

Table 2. Analysis of Dialogue 2.

\begin{tabular}{|c|l|}
\hline Components & \multicolumn{1}{c|}{ Explanation } \\
\hline S & $\begin{array}{l}\text { Toula is doing paperwork at home, and her father comes to the room where she is } \\
\text { working. }\end{array}$ \\
\hline P & Speakers are Toula and her father. \\
\hline E & Toula wants to ask her father for permission to go to college. \\
\hline A & $\begin{array}{l}\text { Toula explains in a hesitant way her willingness to go to college by providing } \\
\text { different reasons. Her father is shocked, he feels being threatened and reacts in a } \\
\text { highly offensive way. Toula reassures her position. Finally, her father orders her to } \\
\text { get married and have babies. }\end{array}$ \\
\hline I & $\begin{array}{l}\text { Toula is very nervous as she knows her father is not going to like what she has to ask } \\
\text { him. She is continuously hesitating as she knows her request is highly face- } \\
\text { threatening. Her eyes and attitudinal behaviour show she fears her father's reaction. }\end{array}$ \\
\hline $\begin{array}{l}\text { Informal conversation between a daughter and her father showing a close social } \\
\text { relationship. However, the tone is very softened and mitigated as it is a very } \\
\text { impositive request given the higher power status of the father. }\end{array}$ \\
\hline
\end{tabular}




\begin{tabular}{|c|l|}
\hline N & $\begin{array}{l}\text { Between a daughter and her father. The stereotype of the woman in the Greek } \\
\text { culture, whose gender confines her to stay at home and take care of the family. }\end{array}$ \\
\hline G & Face-to-face conversation. \\
\hline
\end{tabular}

After conducting a detailed scene analysis of both film dialogues following the eight components of the SPEAKING framework, a contextual analysis should take place and precede the linguistic one. Table 2 presents sample general awareness-raising questions for both analyses.

Table 3. Sample Questions for the Contextual and Linguistic Analysis (adapted from McConachy, 2009, and Usó-Juan \& Martínez-Flor, 2008, respectively)

\begin{tabular}{|l|l|}
\hline \multicolumn{2}{|c|}{$1^{\text {st }}$ step. Sample Awareness-Raising Questions for the Contextual Analysis } \\
\hline \multicolumn{1}{|c|}{ Focus } & \multicolumn{1}{c|}{ Questions } \\
\hline S & Where are the interactants having this conversation? \\
\hline P & What is the social relationship between participants? \\
\hline $\mathrm{E}$ & What is the participants' goal for having this conversation? \\
\hline $\mathrm{A}$ & How is the sequence of the conversation developed? \\
\hline $\mathrm{K}$ & What clues let us know the tone of communication or feelings of the speakers? \\
\hline $\mathrm{I}$ & Is the language used in this conversation polite, casual, or in-between? \\
\hline $\mathrm{N}$ & Can interactional norms for politeness be observed in the conversation? \\
\hline $\mathrm{G}$ & What type of discourse is this interaction? \\
\hline \multicolumn{1}{|c|}{$2^{\text {nd }}$ step. Sample Awareness-Raising Questions for the Linguistic Analysis } \\
\hline \multicolumn{2}{|c|}{ Questions } \\
\hline Requestive act & Can you identify the main request head act(s)? \\
\hline Request modifiers & Can you identify the types of request modification devices being used? \\
\hline Functions & Which function does each request modification device have? \\
\hline
\end{tabular}

The above-described analysis may help learners realise the fact that sociocultural factors (i.e., physical setting, participants' relationship, goal of the conversation, cultural aspects, among others) shape the linguistic choices of the interactants. That is to say, once the learners have a good understanding of what to look for and pay attention to in the contextual analysis, the linguistic analysis can proceed. To elaborate, in dialogue 1 , the interactants did not know each other in person, and Terry's request was formulated in a formal way to get what he wanted, that is, a conversation with Jack about his theory on abrupt climate shift; once they knew each other, language turned more informal. However, in dialogue 2, despite the close relationship among Toula and his father, Toula's request was highly mitigated with preparators, fillers, and grounders, which supported the main communicative goal of the interaction, that is, asking her father for permission to go to college. 
Alongside the above-described analysis of film dialogues, representative techniques from the three theoretical paradigms previously discussed can be used to foster learners' (meta)pragmatic awareness of request modifiers. These techniques could include:

- Encouraging learners' own discovery of request modifiers in films (Alcón-Soler, 2007). Here, teachers may ask learners to view a film outside the classroom and collect conversations with contrasting scenarios which contain a variety of request modification devices. In class, learners could be asked to answer the awarenessraising questions displayed in Table 2 .

- Promoting learners' active engagement in comparisons between the use of request modification devices in their L1 and the TL (Takahashi, 2013). Guided by the awareness-raising questions presented in Table 2, learners can engage in classdiscussion about how they perceive actions in a particular conversation.

- Constructing learners' understanding of how request modifiers are used by asking them to verbalise dialogic tasks, that is to say, tasks in which a learner explains his understanding of pragmatic concepts to another person (van Compernolle, 2014). In being prompted to externalise their internal mental activity, these activities may improve learners' existing knowledge of pragmatics. Here, learners could be asked to verbalise their thinking about the aspects they pay attention to for the appropriate selection of a particular request modifier while completing the eight components of the SPEAKING framework for a given film dialogue.

- Engaging learners in collaborative dialogue to construct (meta)pragmatic interpretations about the appropriate use of request modifiers while conducting intercultural comparisons (McConachy, 2018). This can be done by presenting learners with film dialogues which include speakers from different L1s and cultures and asking them to judge their pragmatic behaviour.

\section{CONCLUSION}

The aim of the present paper was to illustrate how learners' (meta)pragmatic awareness can be raised through film analysis. By means of developing awareness-raising questions for a contextual and linguistic analysis of film dialogues and implementing researchbased techniques, which promote reflective thinking, learners can be guided in the 
process of enhancing their pragmatic ability. Although the proposed analysis focused on request modification devices, the sample questions presented could easily be adopted for other pragmatic features, such as different speech acts (i.e., apologies, refusals, suggestions), implicature or humour, among others. It is our hope that the type of filmbased dialogue analysis here presented may be used by teachers as a model to incorporate (meta)pragmatic awareness-raising activities in their daily teaching practices.

\section{Acknowledgements}

As members of the LAELA (Lingüística Aplicada a l'Ensenyament de la Llengua Anglesa) research group at Universitat Jaume I (Castellón, Spain), we would like to acknowledge that this study is part of a research project funded by (a) the Universitat Jaume I (UJI-B2019-23), and (b) Projectes d'Innovació Educativa de la Unitat de Suport Educatiu 3975/21 and 3976/21.

\section{REFERENCES}

Abrams, Z. (2014). Using film to provide a context for teaching L2 pragmatics. System, $46,55-64$.

Abrams, Z. (2016). Creating a social context through film: Teaching L2 pragmatics as a locally situated context. L2 Journal, 8(3), 23-45.

Achiba, M. (2003). Learning to request in a second language: Child interlanguage pragmatics. Clevedon, England: Multilingual Matters.

Alcón-Soler, E. (2007). Fostering EFL learners' awareness of requesting through explicit and implicit consciousness-raising tasks. In García-Mayo, M. P. (Ed.), Investigating tasks in formal language learning (pp. 221-41). Clevedon, England: Multilingual Matters.

Arthur, P. (1999) Why use video? A teacher's perspective. VSELT, 2(4).

Bardovi-Harlig, K. (2020). Pedagogical linguistics: A view from L2 pragmatics. Pedagogical Linguistics, 1(1), 44-65.

Bardovi-Harlig, K. \& Dörnyei, Z. (1998). Do language learners recognize pragmatic violations? Pragmatic versus grammatical awareness in instructed L2 learning. TESOL Quarterly, 32(2), 233-259. 
Bardovi-Harlig, K., Mossman, S., \& Vellenga, H. (2015). Developing corpus-based materials to teach pragmatic routines. TESOL Journal, 6(3), 499-526.

Barron, A. (2019). Using corpus-linguistic methods to track longitudinal development: Routine apologies in the study abroad context. Journal of Pragmatics, 146, 87105.

Belz, J. A. \& Kinginger, C. (2002). The cross-linguistic development of address form use in telecollaborative language learning: Two case studies. The Canadian Modern Language Review, 59(2), 189-214.

Belz, J. A. \& Kinginger, C. (2003). Discourse options and the development of pragmatic competence by classroom learners of German: The case of address forms. Language Learning, 53(4), 591-647.

Boxer, D. \& Pickering, L. (1995). Problems in the presentation of speech acts in ELT materials: The case of complaints. ELT Journal, 49, 44-58.

Billmyer, K. (1990). "I really like your lifestyle": ESL learners learning how to compliment. Penn Working Papers in Educational Linguistics, 6(2), 31-48.

Boxer, D. (2003). Critical issues in developmental pragmatics. In A. Martínez-Flor, E. UsóJuan \& A. Fernández-Guerra (Eds.), Pragmatic competence in foreign language teaching (pp. 45-67). Servei de Publicacions de la Universitat Jaume I.

Canning-Wilson, C. (2000). Practical aspects of using video in the foreign language classroom. The Internet TESL Journal, 11.

Cohen, A. D. (2008). Teaching and assessing L2 pragmatics: What can we expect from learners? Language Teaching, 41(2), 213-235.

Cohen, A. D., \& Ishihara, N. (2013). Pragmatics. In B. Tomlinson (Ed.), Applied linguistics and materials development (pp. 113-26). Bloomsbury Academic.

Crystal, D. (1997). The Cambridge encyclopedia of language (2nd ed.) Cambridge University Press.

Fernández-Guerra, A. (2008). Requests in TV series and in naturally occurring discourse: A comparison. In E. Alcón (Ed.), Learning how to request in an instructed language learning context (pp. 111-126). Peter Lang. 
González-Lloret, M. (2018). Pragmatics in technology-mediated contexts. In SánchezHernández, A. \& Herraiz-Martínez, A. (Eds.), Learning second language pragmatics beyond traditional contexts (pp. 17-48). Peter Lang.

Gónzalez-Lloret, M. (2019). Technology and L2 pragmatics learning. Annual Review of Applied Linguistics, 39, 113-127. doi:10.1017/S0267190519000047

Grant, L. \& Starks, D. (2001). Screening appropriate teaching materials. Closings from textbooks and television soap operas. International Review of Applied Linguistics, 39, 39-50.

House, J. \& Kasper, G. (1981). 'Politeness markers in English and German'. In F. Coulmas (Ed.), Conversational routine (pp. 157-185). Mouton de Gruyter.

Hymes, D. (1974). Foundations in sociolinguistics: An ethnographic approach. University of Pennsylvania Press.

Jiang, X. (2006). Suggestions: What should ESL students know? System, 34(1), 36-54.

Kasper, G. (1997). Can pragmatic competence be taught? NetWork, 6. Honolulu: University of Hawaii, Second Language Teaching and Curriculum Center. http://www.nflrc.hawaii.edu/NetWorks/NW06/

Kasper, G. \& Schmidt, R. (1996). Developmental issues in interlanguage pragmatics. Studies on Second Language Acquisition, 18(2), 149-169.

Kecskes, I. (2013). Intercultural pragmatics. Oxford University Press.

Kecskes, I. (2015). How does pragmatic competence develop in bilinguals? International Journal of Multilingualism, 12(4), 419-434.

Kinginger, C. \& Belz, J. A. (2005). Socio-cultural perspectives on pragmatic development in foreign language learning: Microgenetic case studies from telecollaboration and residence abroad. Intercultural Pragmatics, 2(4), 369-421.

Kite, Y. \& Tatsuki, D. (2005). Remedial interactions in film. In D. Tatsuki (Ed.), Pragmatics in language learning, theory and practice (pp. 99-117). Tokyo, JALT, The Japan Association for Language Teaching, Pragmatics Special Interest Group.

Kozloff, S. (2000). Overhearing film dialogue. University of California Press. 
Liddicoat, A. J. (2006). Learning the culture of interpersonal relationships: Students' understandings of personal address forms in French. Intercultural Pragmatics, $3(1), 55-80$.

Liddicoat, A. J. \& Scarino, A. (2013). Intercultural language teaching and learning. WileyBlackwell.

LoCastro, V. (2003). An introduction to pragmatics: Social action for language teachers. Michigan Press.

Manes, J. \& Wolfson, N. (1981). The compliment formula. In F. Coulmas (Ed.), Conversational routine: Explorations in standardized communication situations and prepatterned speech (pp. 115-132). Mouton de Gruyter.

Martínez-Flor, A. (2007). Analysing request modification devices in films: Implications for pragmatic learning in instructed foreign language contexts. In E. Alcón \& M.P. Safont (Eds.), Intercultural language use and language learning (pp. 245-280). Springer.

Martínez-Flor, A. \& Fernández-Guerra, A. (2002). Coursebooks and films in foreign language teaching: A pragmatic approach. SELL: Studies in English Language and Linguistics, 4, 181-206.

Martínez-Flor, A. \& Usó-Juan, E. (2010). Pragmatics and speech act performance. In A. Martínez-Flor \& E. Usó-Juan, E. (Eds.), Speech act performance. Theoretical, empirical and methodological issues (pp. 3-20). John Benjamins.

Martínez-Flor, A. \& Usó-Juan, E. (2020). Teaching speech acts in a second language. In K. P. Schneider \& E. Ifantidou (Eds.), Developmental and clinical pragmatics (pp. 269-299). Mouton de Gruyter.

McConachy, T. (2009). Raising sociocultural awareness through contextual analysis: some tools for teachers. ELT Journal, 63(2), 116-125.

McConachy, T. (2018). Developing intercultural perspective on language use: Exploring pragmatics and culture in foreign language learning. Multilingual Matters. 
McConachy, T. \& Spencer-Oatey, H. (2020). Developing pragmatic awareness. In K. P. Schneider \& E. Ifantidou (Eds.), Developmental and clinical pragmatics (pp. 393427). Mouton de Gruyter.

Nguyen, T. T. M. (2011). Learning to communicate in a globalized world: To what extent do school textbooks facilitate the development of intercultural pragmatic competence? RELC Journal, 42(1), 17-30.

Nikula, T. (1996). Pragmatic force modifiers. A study in interlanguage pragmatics. University of Jyväskylä.

Ren, W. \& Zhengrui, H. (2016). The representation of pragmatic knowledge on recent ELT textbooks. ELT Journal, 70(4), 424-434.

Rose, K. R. (1993). Sociolinguistic consciousness-raising through video. The Language Teacher, 17, 7-9.

Rose, K. R. (1994). Pragmatic consciousness-raising in an EFL context. In L. F. Bouton \& Y. Kachru (Eds.), Pragmatics and language learning, vol 5 (pp. 52-63). University of Illinois at Urbana-Champaign.

Rose, K. R. (1997). Pragmatics in the classroom: Theoretical concerns and practical possibilities. In L. F. Bouton \& Y. Kachru (Eds.), Pragmatics and language learning, vol 8 (pp. 267-295). University of Illinois at Urbana-Champaign.

Rose, K. R. (1999). Teachers and students learning about requests in Hong Kong. In E. Hinkel (Ed.), Culture in second language teaching and learning (pp. 167-180). Cambridge University Press.

Rose, K. R. (2001). Compliments and compliment responses in film: Implications for pragmatics research and language teaching. International Review of Applied Linguistics, 39, 309-326.

Rossi, F. (2011). Discourse analysis of film dialogues: Italian comedy between linguistic realism ad pragmatic non-realism. In M. Piazza, M. Bednarek \& F. Rossi (Eds.), Telecinematic discourse: Approaches to the language of films and television series (pp. 21-46). John Benjamins. 
Ryan, S. (1998). Using films to develop learner motivation. The Internet TESL Journal vol IV, 11.

Ryan, J. \& Granville, S. (2020). The suitability of film for modelling the pragmatics of interaction: Exploring authenticity. System, 89.

Schauer, G. A. (2006). Pragmatic awareness in ESL and EFL contexts: Contrast and development. Language Learning, 56(2), 269-318.

Schauer, G. A. (2009). Interlanguage pragmatic development: The study abroad context. London: Continuum.

Schauer, G. A. \& Adolphs, S. (2006). Expressions of gratitude in corpus and DCT data: Vocabulary, formulaic sequences, and pedagogy. System, 34(1), 119-134.

Segovia, R. (2008). The social context of the 68 in the film discourse: Milou en Mai. Dossiers Feministes, 12, 99-119.

Sherman, J. (2003). Using authentic video in the language classroom. Cambridge University Press.

Sifianou, M. (1999). Politeness phenomena in England and Greece. A cross-cultural perspective. Oxford University Press.

Sykes, J. M. (2013). Multiuser virtual environments: Learner apologies in Spanish. In N. Taguchi \& J. M. Sykes (Eds.), Technology in interlanguage pragmatics research and teaching (pp. 71-100). John Benjamins.

Swaffar, J. \& Vlatten, A. (1997). A sequential model for video viewing in the foreign language curriculum. The Modern Language Journal, 81(1), 175-188.

Taguchi, N. (2011). Teaching pragmatics: Trends and issues. Annual Review of Applied Linguistics, 31, 289-310.

Takahashi, S. (2013). Pragmatic awareness in second language learning. In C. A. Chapelle, (Ed.), The encyclopedia of applied linguistics (pp. 4505-4509). Wiley-Blackwell.

Takimoto, M. (2007). The effects of input-based tasks on the development of learners' pragmatic proficiency. Applied Linguistics, 30(1), 1-25. 
Tatsuki, D. (2019). Instructional material development in L2 pragmatics. In Taguchi, N. (Ed.), The Routledge handbook of second language acquisition and pragmatics (pp. 322-337). Routledge.

Tatsuki, D. \& Nishizawa, R. (2005) A comparison of compliments and compliment responses in television interviews, film, and naturally occurring data. In Tatsuki, D. (Ed.), Pragmatics in language learning, theory and practice (pp. 87-97). Tokyo, JALT, The Japan Association for Language Teaching, Pragmatics Special Interest Group.

Ton-Nu, A. T. \& Murray, J. (2020). Pragmatic Content in EFL Textbooks: An Investigation into Vietnamese National Teaching Materials. TESL Electronic Journal, 24(3), 128.

Toolan, M. (2011). “I don't know what they're saying half the time, but I'm hooked on the series": Incomprehensible dialogue and integrated multimodal characterisation in the Wire. In M. Piazza, M. Bednarek \& F. Rossi (Eds.), Telecinematic discourse: Approaches to the language of films and television series (pp. 161-184). John Benjamins.

Trosborg, A. (1995). Interlanguage pragmatics. Requests, complaints and apologies. Mouton de Gruyter.

Usó-Juan, E. (2007). The presentation and practice of the communicative act of requesting in textbooks: Focusing on modifiers. In E. Alcón \& M. P. Safont (Eds.), Intercultural language use and language learning (pp. 223-244). Springer.

Usó-Juan, E. (2008). A pragmatic-focused evaluation of requests and their modification devices in textbook conversations. In E. Alcón (Ed.), Learning how to request in an instructed language learning context (pp. 65-90). Peter Lang.

Usó-Juan, E. (2010). Requests. A sociopragmatic approach. In A. Martínez-Flor \& E. UsóJuan (Eds.), Speech act performance. Theoretical, empirical and methodological issues (pp. 237-256). John Benjamins.

Usó-Juan, E. \& Martínez-Flor, A. (2008). Teaching learners to appropriately mitigate requests. ELT Journal, 62(4), 349-357. 
van Compernolle, R. A. (2014). Sociocultural theory and L2 instructional pragmatics. Bristol: Multilingual Matters.

van Compernolle, R. A. \& Kinginger, C. (2013). Promoting metapragmatic development through assessment in the zone of proximal development. Language Teaching Research, 17(3), 282-302.

van Compernolle, R. A., Gomez-Laich, M. P. \& Weber, A. (2016). Teaching L2 Spanish sociopragmatics through concepts: A classroom-based study. Modern Language Journal, 100(1), 341-361.

Vellenga, H. (2004). Learning pragmatics from ESL and EFL textbooks: How likely? TESL Electronic Journal, 8(2), 1-18.

Yamanaka, M. (2003). The use of movies in EFL tuition. The Journal of Gifu Women's University, 43-49.

Zand-Vakili, E., Kashani, A.\& Tabandeh, F. (2012). The analysis of speech events and Hymes' SPEAKING factors in the comedy television series: "FRIENDS". New Media and Mass Communication, 2, 27-43.

Zhao, Y. \& Liu, J. (2019). Screenplays as a Pedagogical Medium for Cultivating EFL Learners' Metapragmatic Awareness of Speech Acts in Spoken English. In Jones, C. (Ed.), Literature, spoken language and speaking skills in second language learning (pp. 118-148). Cambridge University Press. 


\section{APPENDIX}

Awareness-raising questions (adopted from Usó-Juan \& Martínez-Flor, 2008, p. 353)

Pragmalinguistic questions:

- How many request head acts have you thought of?

- How many request mitigating devices have you thought of?

- Can you arrange the request head acts on a directness scale?

- Can you organise the request mitigating devices according to their types and functions?

Sociopragmatic questions:

- Which different request head acts and mitigating devices have you found depending on the degree of familiarity that exists between the speakers?

- Which different request head acts and mitigating devices have you found depending on the speaker's power over the hearer?

- Which different request head acts and mitigating devices have you found depending on the degree of imposition involved in the request?

- $\quad$ Are the interactional and contextual factors important when selecting a particular request head act and its mitigating devices?

Received: 25 March 2021

Accepted: 26 July 2021 